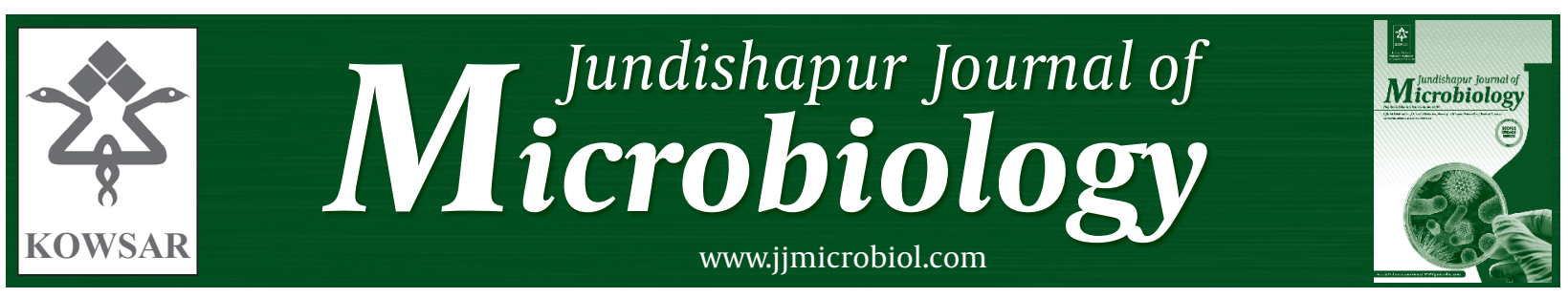

\title{
Jundishapur, A Symbol of Intercultural Understanding
}

\author{
Mohammad Reza Afshar ${ }^{1^{*}}$ \\ ${ }^{1}$ Department of English \& General Courses, Ahvaz Jundishapur University of Medical Sciences, Ahvaz, IR Iran
}

A R T I C L E I N F O

Article type:

Editorial

Article history:

Received: 30 Jun 2012

Revised: 01 Jul 2012

Accepted: 03 Jul 2012

Keywords:

Jundishapur

Ahvaz

\section{Introduction}

Acquisition of knowledge and cultural cooperation with the other civilized nations has been the most important art of the Iranian. This is evident if you study about Jundishapur University, which was established during the Shapur II reign (309-379 AD) in the city of Gondeshapur (1). The remains of the university still exist in Shahabad, a village $14 \mathrm{~km}$ southeast of Dezful, to the road for Shush, in the present-day province of Khuzestan, southwest Iran (Wikipeia). In the very past, medicine, philosophy, theology, basic sciences, especially astronomy, have been studied at the university. There were educational hospital, a pharmacology laboratory, an observatory, and a large library with books and manuscript in Pahlavi, Greek, Indi and Syrian. This university was considered as a model when Bayt al-hikmah (house of wisdom) was established in Baghdad (2).

\section{University Development}

Frye, quoted by Pourahmad (3), says that in a Pahlavi text, Karnamag, Anushirwan declared, "We have never
- Implication for health policy/practice/research/medical education:

The goal is to give a general view of Jundishapur University and encourage medical researchers of different cultures and countries to cooperate with each other.

- Please cite this paper as:

Afshar MR. Jundishapur, A Symbol of Intercultural Understanding. Jundishapur J Microbiol. 2012;5(4):519-20. DOI:10.5812/jjm.6978

Published by Kowsar Corp, 2012. cc 3.0.

rejected anybody because of their different religion or origin. We have not jealously kept away from them what we affirm". He had knowledge of philosophy and paid special attention to the scholars, physicians and translators (4). The king's broad-mindedness prepared the way for the development of the university. This is why most of the skillful physicians came to the city to join the medical centers. Because of the pleasant personality of the kings, especially Anoshirwan, and their warm reception, scientists and physician with different philosophical opinion from India, Egypt, and Greece joined at the University of Jundishapur. In 489AD, Nestorians branded heretic by the Catholic Church came to the city of Jundishapur due to the closing of the Edessa School by Emperor Zeno (2).

In 529AD, seven scientists and philosophers (Damascius, Siplicius, Eulamius, Priscianus, Isidore, Hermias, and Diogenes) from east Roman Empire immigrated to Iran because of the closing of their academy by Justinian, the East Roman emperor (2). Borzuyeh commissioned by Anushirwan to learn Indian knowledge of medicine brought some books, scholars and families to Iran (2). People of several ethnic groups lived in the city and the

\footnotetext{
${ }^{*}$ Corresponding author: Mohammad Reza Afshar, Department of English \& General Courses, Jundishapur University of Medical Sciences, Ahvaz, IR Iran. Tel: +989166154570, Fax:+98-06113332036, E-mail:mr_afshar@yahoo.com 
languages of Pahlawi, Syriac, Greek, Khuzi, Lurian, and Hebrew were spoken in the market (2). Generally, due to the ethnic diversity people coexisted peacefully and reached to a high level of cultural understanding.

Medical education was more important than astronomy and philosophy and it was a blend of Indian, Greek, and Iranian medicine. Due to the cooperation of scientists of different nations, the progress of medical science was considerable. According to the Arab historian, AlQifti, quoted by Gail Marlow Taylor (4) of the university of California, the science of medicine was more advanced in Iran in comparison to Greek and Indian. However, Godishapur School of medicine was known as "the city Hippocrates" probably because he was respected or had influential scientific character $(1,2)$.

The most skillful physician known as Dorostbad directed the school and the hospital (bimaristan). He was the physician to the emperor and the court's head doctor. Borzuyeh and Jebrail served in this position during the sasanid and Muslim, respectively (2).

Some associations organized meetings and gatherings similar to the seminar and conferences today. In 550, the first medical symposium was held by the order of the king, Khosrow Anoshirwan, who participated in the scientific discussions (1). Scholars from different countries participated in the conferences every year to exchange their knowledge and these events resulted in the development of the university.

\section{The Library}

The Sasanid kings, especially Anushirwan, who was very much bibliophile, paid special attention to the university library. He sent Bozorgmehr who seems to be Borzuyeh, to India to bring useful books and translate them. One of his artistic translations from Sanskrit to Pahlavi is Kaliledemneh, the Sanskrit title is Panchatantra (http://en.wikipedia.org/ wiki/Burzoe). Anushirwan participated in a series of scientific dialogues with Neoplatonian, especially Priscianus. Many books of the questions and answers were written but only an incomplete translation of one of them is available in Saint- German library in Paris (2).

There was a House of Translation (Dar al-Tarjamah) near the hospital in Jundishapur in which a team of translators, many of them physician, cooperated (2). The books available in the library were of various subjects including medicine, veterinary, botany, pharmacy, philosophy and mathematics in Pahlavi, Syriac, Greek and Sanskrit.
Some were translated into the Persian language (Pahlavi) by an international community of scholars including the heretic Nestorian Christians, Jews, Greeks, Syrians, Egyptians, Romans, Chinese, and Indians (5) and the scholars in Gondeshapur had written some. Most of them were translated into Arabic in the Islamic era and some are still available. For example, the Book of poison (Kitab al-Sumum) was translated from Sanskrit into Pahlavi by Abu Hatim al-Balkhi and then into Arabic (2).

\section{Conclusions}

In 636AD, the city of Jundishapur surrendered to the Muslim forces but the university continued to function (4). After the conquest, regarding the prophetic traditions "Seek learning even if it be in China", and " The ink of Scholars is worth more than the blood of martyrs", the Muslim rulers tried to develop hospitals and learning. In 830AD, the Caliph Al-Mamun founded 'Bait-ul-Hekma'or house of wisdom in Baghdad (6). Mahmoodi believes that among some other reasons the establishment of the house of wisdom and financial support of scholars by the Abbasid Caliphs attracted physicians and scientists of Jundishapur. Hence, the decline began and Jundishapur closed 300 years after the emergence of Islam (7). However, the university revived in 1334 /1955AD by the cooperation of professors of the university of Tubingen. Today, Ahvaz Jundishapur University of Medical Sciences which encompasses Seven schools and four educational hospitals is under the supervision of the Ministry of Health and Medical Education and the nonmedical schools are named "Shahid Chamran University of Ahvaz" that is under the supervision of the Ministry of Higher Education. In the end, the authorities, colleagues and all the writers of the articles participate in the glorification of the forgien and Iranian scholars and physicians in the Sasanid and Islamic period.

\section{References}

1. Azizi MH. History of Ancient Medicine in Iran. Arch Iran Med. 2008;11 (1).

2. Soylemez MM. The Jundishapur School, its history, structure, and functions. Am J Islamic Social Sci. 2005;22:1.

3. Pourahmad J. History of Medical Sciences in Iran. Iran J Pharm Res. 2010;7 (2):93-9.

4. Taylor GM. The Physicians of Jundishapur. e-sasanika. 2010;11.

5. George D. A Golden Thread: The Transmission of Western Astrology Though Cultures. The Mountain Astrologer Magazine. 2003.

6. Nagamia HF. Islamic medicine history and current practice. J Int Soc His Islam Med. 2003;2:19-30.

7. Mahmudi AA. [History of Islam]. Jundishapur. 1384;23. 